\title{
Does Corporate Governance Moderate the Relationship between Liquidity Ratios and Financial Performance? Evidence from Indian Pharmaceutical Companies
}

\author{
Najib H.S. Farhan ${ }^{1}$ \\ Eissa Alhomidi ${ }^{1}$ \\ Faozi. A. Almaqtari ${ }^{1}$ \\ Mosab I. Tabash ${ }^{2}$ \\ ${ }^{1}$ Department of Commerce, Aligarh Muslim University, Aligarh, UP, India \\ ${ }^{2}$ Assistant Professor, Al Ain University of Science and Technology, United Arab Emirates
}

Doi: 10.36941/ajis-2019-0013

\begin{abstract}
The current study is going to examine the impact of liquidity ratios on the financial performance of Indian pharmaceutical companies. Furthermore, it attempts to find out whether corporate governance moderates the relationship between liquidity and firms' performance. The analysis of this paper is based on a panel data approach of 82 pharmaceutical companies, for the period from 2008 to 2017. GMM model is used for estimating the results. Two accounting-based measures and one marketing based measure are used as proxies for firms' financial performance. Current ratio and quick ratio are used as proxies for independent variables. Leverage and firms' size are used as control variables. The study found that the current ratio and quick ratio significantly and positively impact pharmaceutical companies' financial performance measured by return on assets and Tobin Q. Moreover, it was found that corporate governance moderates the relationship between current ratio, quick ratio, and net operating margin. It seems that the impact of liquidity ratios on firms' performance has been over-studied and the literature is overwhelming. However, this study adds a new contribution to the existing literature by introducing a corporate governance as a moderation factor.
\end{abstract}

Keywords: liquidity ratios, financial performance, moderation effect, corporate governance, GMM estimation

\section{Introduction}

Liquidity points out to the ability of a firm in paying back its short-term liabilities. It plays a vital role in smoothing all operations of a firm. Studying liquidity is very useful to both external and internal analysts due to its impact on firms' day to day operations (Elangkumaran \& Karthika, 2013). Liquidity is a prerequisite for a firm as it shows its ability for meeting its short-term obligations. Quick ratio and current ratio are considered to be the standard measures of liquidity position of a company. Current ratio sets the association between short-term assets and short-term liabilities. Generally, when the current ratio is high, we can say that the firm's ability to pay back its short-term obligations is good whereas the quick ratio sets the correlation between current liabilities and current assets. When assets are liquid, it means that they can be converted into cash quickly without loss. Low current ratio indicates that a company cannot pay its obligations on time to creditors, services and goods suppliers (Owolabi, Obiakor, \& Okwu, 2011). Wang (2002) found that aggressive liquidity management boosts the operating performance of a firm and usually result 
in higher values for a firm. Managing liquidity efficiently leads to eliminating the risk of inability to meeting short-term liabilities when it's due on the one hand. On the other hand, it helps in avoiding excessive investment in these assets (Priya \& Nimalathasan, 2013). Profitability's information is crucial for decision making, and it is used by many people in the company such as managers, investors, and financial analysts as a guide for dividends payment, management efficiency tool measurement and instrument for decision making an evaluation (Nassirzadeh \& Rostami, 2010). Profitability and liquidity are of substantial issue that all commercial units should keep studying and thinking about, as one of the most crucial duties. Some authors believe that there is great importance for liquidity because companies that achieve low profitability or zero can serve the economy whereas firms without liquidity cannot serve the economy well (as cited in (Nassirzadeh \& Rostami, 2010). Liquidity plays a vital role in determining the level of profitability of a company (Zygmunt, 2013). (Wang, 2002; Ware, 2015) advocated that there is a negative relationship between liquidity and profitability. Eljelly (2004) showed a negative correlation between liquidity and profitability. Some liquidity variables have positive, and some others have a negative association with profitability (e.g., Bhunia, 2013; Bibi \& Amjad, 2017; Egbide, Uwuigbe, \& Uwalomwa, 2013; Nassirzadeh \& Rostami, 2010; Priya \& Nimalathasan, 2013). There is a significant negative association between the firm's profitability and its liquidity (Eljelly, 2004). Cash gap has a significant negative relationship with return on assets, whereas current ratio, log of sales and log of total assets have a significant positive correlation with ROA (Bibi \& Amjad, 2017). Profitability has a substantial and negative relationship with current ratio and cash conversion cycle, whereas it has a significant and positive relationship with the liquid ratio, net liquid balance index, and comprehensive liquidity index (Nassirzadeh \& Rostami, 2010).

Corporate governance can be defined as the process and structure that is used for directing and managing business' affairs to enhance business prosperity and corporate accountability with the ultimate objective (Zabri, Ahmad, \& Wah, 2016). (Bhagat \& Bolton, 2008; Chauhan, Lakshmi, \& Dey, 2016; Duffhues \& Kabir, 2008; Yang \& Zhao, 2014) Argue that corporate governance directly correlates with firm performance. The point of view of the individual companies, sound corporate governance practices should result in better financial opportunities, lower cost of capital, facilitation of the provision of funds in international financial markets, the better chance of overcoming crisis periods and increased liquidity (Nilsson, 2007). It is strongly recommended that for effective working capital policies, the formulation of such policies must be done with the recognition of corporate governance practices (Achchuthan \& Kajananthan, 2013).

Management of Profitability and liquidity are substantial issues for growth and survival as well (Priya \& Nimalathasan, 2013). The effects of liquidity management on firms' performance have gained dramatic attention in the literature of working capital management. Depth understanding of liquidity historical perspectives will make sense for its practices today and likely future directions. The current study is going to examine the impact of liquidity ratios on the financial performance of Indian pharmaceutical companies. Furthermore, this study contributes to the existing literature by attempting to find out if corporate governance moderates the relationship between liquidity and firms' performance. The remainder of this study is organized as follow: Section 2 reviews the previous literature, section 3 provides an overview of Indian pharmaceutical sector, section 4 demonstrates the research methodology, section 5 discusses the findings, and section 6 concludes the study.

\section{Literature Review}

Liquidity management has been investigated extensively in different countries around the world. Although there are two common ratios for measuring liquidity in the existing literature, most of the conducted studies have the same purposes and outlines. The body of this chapter is extensively focusing on the results, variables, and the statistical techniques which were used in previous literature to find the appropriate approach for investigating the research hypothesis. A number of prior studies focused on the association between liquidity and profitability, the establishment of such a relationship is not simple, and researchers used different types of measures for exploring the relationship between liquidity and profitability. On the one hand, many studies (e.g. Bhunia, 
Khan, \& MuKhuti, 2011; Elangkumaran \& Karthika, 2013; Khidmat \& Rehman, 2014; Morgheim, 2015; Niresh, 2012a; Owolabi et al. 2011; Rehman, Khan, \& Khokhar, 2015; Saleem \& Rehman, 2011) used current ratio, liquidity ratio and some other ratios for measuring liquidity which resulted different findings. Various studies (e.g. Bhunia et al., 2011; Elangkumaran \& Karthika, 2013; Khidmat \& Rehman, 2014; Owolabi et al., 2011, Al-Homaidi et al., 2019) found a positive correlation between liquidity and profitability, whereas others (Morgheim, 2015; Rehman et al., 2015) found a negative relationship between liquidity and profitability. However, some of the traditional indices of measuring liquidity have a positive relationship with profitability whereas some others have a negative association (Rehman et al., 2015; Saleem \& Rehman, 2011).

On the other hand, various studies (e.g., Owolabi \& Obida, 2012; Wang, 2002; Ware, 2015) investigated the trade-off between liquidity and profitability. Interestingly, others (Wang, 2002; Ware, 2015) advocated that there was a negative relationship between liquidity and profitability. Owolabi \& Obida (2012) believe that cash conversion cycle has a positive association with ROE and negative association with ROA. In an attempt to empirically examine the relationship between liquidity and profitability scholars from Saudi Arabia, Pakistan, Poland, India, Iran, Sri Lanka, Nigeria, and Pakistan conducted their research and they came up with different findings.

Some researchers (e.g., Mushtaq, Chishti, Kanwal, \& Saeed, 2015; Zygmunt, 2013) tried to explore the relationship between liquidity and profitability of 460 Pakistani and 10 Polish companies, respectively. Descriptive statistics, correlation, and regression techniques were used for analyzing the data. A positive and moderate positive association was found between liquidity and profitability. On the contrary, Eljelly (2004) analyzed the association between working capital management and firm's performance for a sample of 29 joint stock companies in Saudi Arabia, using descriptive statistics, correlation matrix and a regression model for analyzing data. The result of the study showed a negative correlation between liquidity and profitability.

Despite the above evidence, studies (e.g. Bhunia, 2013; Bibi \& Amjad, 2017; Egbide et al. 2013; Nassirzadeh \& Rostami, 2010; Priya \& Nimalathasan, 2013) attempted to empirically examine the trade-off between liquidity and profitability of 100 SMEs, 50, 30, 108 and 10 companies, respectively. Correlation and regression techniques were applied for data analysis. The results affirmed that some liquidity variables have positive and some others have a negative association with profitability. Steel companies maintain adequate liquidity which correlates positively with profitability indicators. Consistently, Bhunia (2013) advocated that the liquidity position was sound and there was a correlation between liquidity and profitability indicators.

Corporate governance concerns all aspects of a firm; this study believes that corporate governance may play the role of moderation between liquidity and profitability. Board composition is going to proxy corporate governance. The board directors include several executives who might be a non-independent or independent director. The board provides an essential work as he monitors the management team of the firm. A large number of independent directors is preferable for investors; it is also called outside director (Muniandy \& Hillier, 2015). Many studies were conducted to investigate the association between board independence and firm's performance. Agrawal \& Knoeber (1996) found that there is a positive association between firms' value and board independence, whereas Jackling \& Johl (2009) believes that here firm performance is positively impacted by board independence. There is a low positive association between board composition and financial performance(Rhoades, Rechner, \& Sundaram, 2017). Johl., Kaur \& Cooper (2015) advocate that board independence has no impact on financial performance. The present study is following the previous approaches in the literature to measure firms' liquidity and profitability.

\section{Overview of Pharmaceutical Industry}

Indian pharmaceutical market is the fastest-growing market in the world. It has set itself as a worldwide manufacturing and research center. India has a massive number of scientists and engineers who can boost the industry to a very high and competent level. Indian Pharmaceutical Industry listed first among other science-based industries with tremendous abilities in drug manufacturing and technology. It is well known for being an organized sector (Padiya, 2015). The industry is estimated to be worth $\$ 4.5$ billion, with annual growth of between $8 \%$ to $9 \%$. In terms of 
the range of medicines manufactured and technology used the industry ranks third in the world. The industry meets approximately $70 \%$ of the country's demand for drug intermediates, bulk drugs, pharmaceutical formulations, capsules, oral tablets, and chemicals. The industry produces around $10 \%$ of global production (Geethalakshmi \& Jothi, 2016; Pandey, Sugumari, \& Azhagaiah, 2016). There are more than 20,000 registered units in the pharmaceutical sector, approximately 250 units are large and control about 70 per cent of the market and around 8000 small units that are considered as the core of the Industry in the country (including 5 central public sector companies) (Geethalakshmi \& Jothi, 2016; Vijayalakshmi \& Srividya, 2015). The industry consists of three sectors. Firstly, public sector undertakings secondly, the private sector thirdly, the foreign sector. There are about 250 large-scale units including the five national undertaking companies and the six FERA companies, they all fall in the organized sector. This organized sector accounts for $70 \%$ of the industry's production (Shah, 2000).

The Annual turnover of Pharmaceutical Industry during the financial year $2015-16$ is 1 , 85,388 crores. This figure represented a decrease of $7.4 \%$ over the figure for the financial year 2014-15. During the last five financial years, the CAGR was $8.88 \%$ (Department of Pharmaceuticals, 2017). The pharmaceuticals market is anticipated to expand at a compound annual growth rate of $23.9 \%$ to reach US $\$ 55$ billion by 2020 (Padiya, 2015). The domestic market of pharmaceutical witnessed a decline in the financial year 2016-17, that is attributed to the efforts of the government in order to make medicines affordable and accessed by all people. The industry showed poor sales performance during two successive quarters ended in September 2016, after that the industry reported grow in sales performance by only $2.9 \%$ in the September 2016 quarter. The industry witnessed rose by $5.4 \%$ in its operating expenses during the September 2016 quarter, which is far faster than the growth in the performance of sales

\section{Research Methodology}

\subsection{Data and sample selection}

This study relies on secondary data that are extracted from ProwessIQ database. Financial data covers ten years from 2008 to 2017 . Two approaches or methods seem to be dominantly adopted for measuring liquidity; these are quick ratio and current ratio. The quick ratio is the ratio of current assets net of inventory to current liabilities whereas current ratio represents the ratio of current assets to current liabilities. Moreover, the current ratio and the quick ratio are used to measure corporate liquidity depending on timely monitoring of balance sheet data and to evaluate whether the firm can pay off liabilities using liquidating assets (Farris., Theodore \& Hutchison, 2002). However, many authors such as (e.g.(Emery, 1984; Kamath, 1989) found faults in these measures, due to their static nature. Nevertheless, their criticism did not affect the use of these ratios as measures for corporate liquidity (e.g., Bhunia et al. 2011; Bibi \& Amjad, 2017; Elangkumaran \& Karthika, 2013; Eljelly, 2004; Morgheim, 2015; Saleem \& Rehman, 2011; Zygmunt, 2013). The study used two accounting based measures, return on assets and net operating margin, and one marketing based measure Tobin $Q$ as proxies for firms' financial performance. Table (1) shows the study variables name, symbols, formula and their use in previous literature.

Table 1: Variables descriptions

\begin{tabular}{|l|l|l|l|}
\hline Variables & Symbo & Formula & Existing studies \\
\hline $\begin{array}{l}\text { Return on } \\
\text { assets }\end{array}$ & ROA & $\begin{array}{l}\text { Net income divided by total } \\
\text { assets at the end of the year. }\end{array}$ & $\begin{array}{l}\text { (Bibi \& Amjad, 2017; Elangkumaran \& Karthika, 2013; Khidmat \& } \\
\text { Rehman, 2014; Morgheim, 2015; Saleem \& Rehman, 2011, Yahya et } \\
\text { al, 2017; Tabash, et al, 2017) }\end{array}$ \\
\hline $\begin{array}{l}\text { Net operating } \\
\text { margin }\end{array}$ & NOM & $\begin{array}{l}\text { Operating profit divided by net } \\
\text { sales. }\end{array}$ & $\begin{array}{l}\text { (Ajao \& Adebayo, 2010; Duncan, Njeru, Member, \& Tirimba, 2015; } \\
\text { Hemalatha \& Under, 2005) }\end{array}$ \\
\hline Tobin Q & TQ & $\begin{array}{l}\text { Market capitalization over a total } \\
\text { asset of the company. }\end{array}$ & $\begin{array}{l}\text { Vahid, Elham, Mohsen, \& Mohammadreza, 2012, Yameen et al, } \\
\text { 2019) }\end{array}$ \\
\hline Current ratio & CR & $\begin{array}{l}\text { Total current assets /total current } \\
\text { liabilities }\end{array}$ & $\begin{array}{l}\text { (Anil, 2015; Bhunia et al., 2011; Bibi \& Amjad, 2017; Eljelly, 2004; } \\
\text { Ganesan, 2007; Raheman, Afza, Qayyum, \& Bodla, 2010; Vahid et } \\
\text { al., 2012) }\end{array}$ \\
\hline
\end{tabular}




\begin{tabular}{|l|l|l|l|}
\hline Variables & Symbol & Formula & Existing studies \\
\hline Quick ratio & QR & Liquid assets/ current liabilities & $\begin{array}{l}\text { Afrifa \& Padachi, 2016; Bhunia et al., 2011; Elangkumaran \& } \\
\text { Karthika, 2013; Khidmat \& Rehman, 2014; Owolabi \& Obida, 2012) }\end{array}$ \\
\hline $\begin{array}{l}\text { Firms size } \\
\text { (log of assets) }\end{array}$ & LOGTA & Natural logarithm of total assets & $\begin{array}{l}\text { (Abuzayed, 2012; Afrifa, 2016; Afrifa \& Padachi, 2016; Banos- } \\
\text { Caballero, Garcla-Teruel, \& Martınez-Solano, 2012; Deloof, 2003; } \\
\text { Mehta, 2017; Pais \& Gama, 2015; Tahir \& Anuar, 2015; Tauringana } \\
\text { \& Afrifa, 2013; Tran, Abbott, \& Yap, 2017; Ukaegbu, 2014; Vahid et } \\
\text { al., 2012; Yunos, Nazaruddin, Ghapar, Ahmad, \& Zakaria, 2015, } \\
\text { Almaqtari et al., 2019) }\end{array}$ \\
\hline Leverage & LEVE & Total debt /shareholder's equity & $\begin{array}{l}\text { (Abuzayed, 2012; Afrifa \& Padachi, 2016; Bagchi, Chakrabarti, \& } \\
\text { Roy, 2012; Banos-Caballero et al., 2012; Deloof, 2003; Mehta, 2017; } \\
\text { Tahir \& Anuar, 2015; Tauringana \& Afrifa, 2013; Tran et al., 2017; } \\
\text { Ukaegbu, 2014; Vahid et al., 2012; Yunos et al., 2015) }\end{array}$ \\
\hline
\end{tabular}

The target population of the study consist of 141 companies which are listed on Bombay Stock Exchange. To ensure that the sample is ideal, the study considers the following criteria.

- The company must have established before 2008.

- $\quad$ Data must be available for the period from March 2008 to March 2017.

- The company must not have any extreme outliers.

Therefore, one company was excluded because of its establishment after the financial year 2008. Forty-one companies did not have data for the study period from March 2008 to March 2017 was dropped from the sample to maintain balanced, structured panel and 17 companies were eliminated from the sample due to the existing of extreme outliers that would affect the results obtained from the regression model. Thus, the final sample consists of 82 companies that met the above criterion. Figure (1) illustrates the process of sample selection.

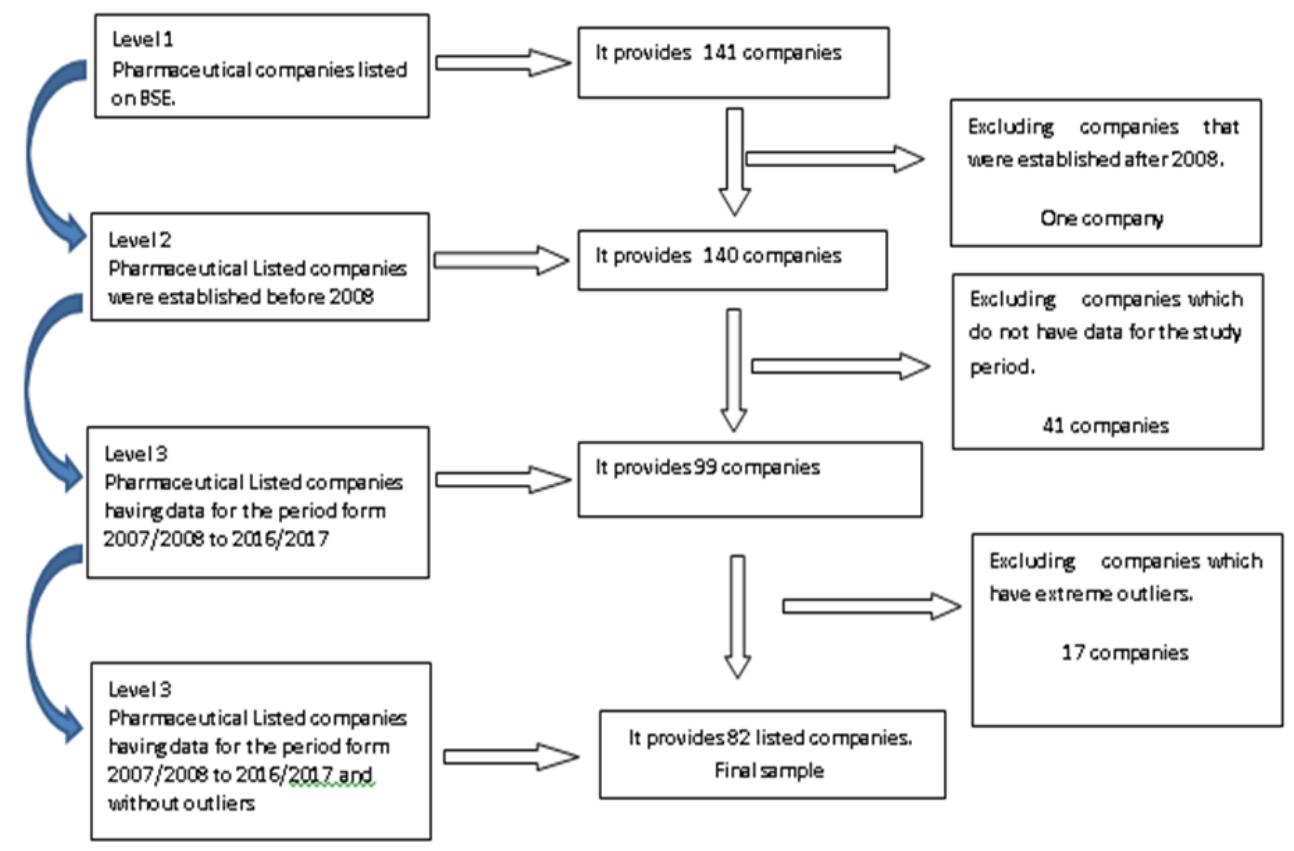

Figure 1: Sample selection process

\subsection{Model specifications}

To examine the impact of liquidity ratios on firm's performance and evaluate the moderation effect of corporate governance (board directors' composition) on the relationship between liquidity ratios and firms' performance, six regression models are designed as follows: 
$(\mathrm{ROA})_{\mathrm{it}=} \alpha+\beta_{1}(\mathrm{CR})_{\mathrm{it}}+\beta_{2}(\mathrm{SIZ})_{\mathrm{it}}+\beta_{3}(\mathrm{LEV})_{\mathrm{it}}+\beta_{4}(\mathrm{BDC} * \mathrm{CR})_{\mathrm{it}}+\varepsilon_{\mathrm{it}}$

$(\mathrm{ROA})_{\mathrm{it}=} \alpha+\beta_{1}(\mathrm{QR})_{\mathrm{it}}+\beta_{2}(\mathrm{SIZ})_{\mathrm{it}}+\beta_{3}(\mathrm{LEV})_{\mathrm{it}}+\beta_{4}(\mathrm{BDC} * \mathrm{QR})_{\mathrm{it}}+\varepsilon_{\mathrm{it}}$

$(\mathrm{NOM})_{\mathrm{it}=} \alpha+\beta_{1}(\mathrm{CR})_{\mathrm{it}}+\beta_{2}(\mathrm{SIZ})_{\mathrm{it}}+\beta_{3}(\mathrm{LEV})_{\mathrm{it}}+\beta_{4}(\mathrm{BDC} * \mathrm{CR})_{\mathrm{it}}+\varepsilon_{\mathrm{it}}$

$(\mathrm{NOM})_{\mathrm{it}=\alpha} \alpha+\beta_{1}(\mathrm{QR})_{\mathrm{it}}+\beta_{2}(\mathrm{SIZ})_{\mathrm{it}}+\beta_{3}(\mathrm{LEV})_{\mathrm{it}}+\beta_{4}(\mathrm{BDC} * \mathrm{QR})_{\mathrm{it}}+\varepsilon_{\mathrm{it}}$

$(\mathrm{TQ})_{\mathrm{it}=} \alpha+\beta_{1}(\mathrm{CR})_{\mathrm{it}}+\beta_{2}(\mathrm{SIZ})_{\mathrm{it}}+\beta_{3}(\mathrm{LEV})_{\mathrm{it}}+\beta_{4}(\mathrm{BDC} * \mathrm{CR})_{\mathrm{it}}+\varepsilon_{\mathrm{it}}$

$(\mathrm{TQ})_{\mathrm{it}=} \alpha+\beta_{1}(\mathrm{QR})_{\mathrm{it}}+\beta_{2}(\mathrm{SIZ})_{\mathrm{it}}+\beta_{3}(\mathrm{LEV})_{\mathrm{it}}+\beta_{4}(\mathrm{BDC} * \mathrm{QR})_{\mathrm{it}}+\varepsilon_{\mathrm{it}}$ assets

$(\mathrm{ROA})$ it = Stands for the financial performance of company $\mathrm{I}$, at time $\mathrm{t}$, measured by return on

$(\mathrm{NOM})$ it = Stands for the financial performance of company I, at time $t$, measured by net operating margin

(TQ $)_{\text {it }}$ Stands for the financial performance of company I, at time $t$, measured by Tobin $Q$

$(C R)_{\text {it }}=$ Current ratio

$(Q R)_{\text {it }}=$ Quick ratio

$(\mathrm{SIZ})_{\text {it }}=$ Size of company $\mathrm{i}$ at time $\mathrm{t}$.

$(\text { LEV })_{i t}=$ Leverage of company $i$ at time $t$.

$\left(B D C^{*} \mathrm{CR}\right)_{\text {it }}=$ is the interaction term that examines the moderation effect of corporate governance on the relationship between current ratio and the financial performance.

$\left(B D C^{*} Q R\right)_{i t}=$ is the interaction term that examines the moderation effect of corporate governance on the relationship between quick ratio and financial performance.

$(\alpha)=$ Common $y$-intercept.

$(\beta 1-\beta 4)=$ coefficients of the explanatory variables

$(\varepsilon)_{\text {it }}=$ Stochastic error term of company $i$ at time

Creation of an interaction term involves two steps. Firstly, the independent and moderator variables must be centered; this centralization is made to overcome the possible multicollinearity problem which would affect the results of the regression mode Secondly, the new centered variables must be multiplied with each other (centered independent variable * centered moderator variable). The moderation is called to exist if the interaction term produces a significant coefficient in predicting the dependent variable (Kim, Kaye, \& Wright, 2001). After introducing the interaction term normality and linearity tests are performed to fitful the assumptions of the regression model. Results of normality and linearity tests are shown in the appendices; appendix (A) shows the normality histogram and appendix (B) linearity P.P plot for all models.

\section{Findings and Analysis}

\subsection{Descriptive Statistics}

Descriptive statistics is the starting point of any statistical analysis; it helps in discovering the abnormalities in the data if any (Butler, Martin, Perryman, \& Upson, 2012). It provides information about the sample statistics.

Table 2: Descriptive statistics

\begin{tabular}{|c|c|c|c|c|}
\hline Variable & Minimum & Maximum & Mean & Std. Deviation \\
\hline ROA & -50.90 & 92.64 & 6.10 & 9.15 \\
\hline NOM & -19.00 & 52.20 & 14.68 & 9.62 \\
\hline TQ & 0.02 & 16.29 & 1.52 & 1.99 \\
\hline CR & 0.24 & 10.89 & 1.70 & 1.22 \\
\hline QR & 0.07 & 10.56 & 1.15 & 1.09 \\
\hline LEVE & 0.00 & 104.60 & 1.94 & 9.36 \\
\hline LOGTA & 3.68 & 12.87 & 8.26 & 1.86 \\
\hline BDC & 0.00 & 0.88 & 0.53 & 0.12 \\
\hline $\begin{array}{l}\text { ROA) return on assets, (NOM) net operating margin, (TQ) Tobin Q, (, (SIZ) Size of company (LEV) } \\
\text { Leverage of company, (CR) current ratio, (QR) quick ratio }\end{array}$ \\
\hline
\end{tabular}


The current ratio is one of the working capital liquidity ratios that are used for measuring firms' liquidity. Table 2 shows that the mean of current ratio is 1.70 . The minimum current ratio of pharmaceutical companies is 0.24 percent while the maximum is 10.89 percent with a standard deviation of 1.22 percent. This indicates that pharmaceutical companies listed on BSE are highly liquid. The quick ratio is the second liquidity ratio used in this study for measuring firms' liquidity. Results in Table 2 demonstrates all statistics values of quick ratio, the average quick ratio is 1.15 , and the minimum and maximum values are 0.07 and 10.56 respectively, with a standard deviation of 1.09. Size of firms is measured by the log of total assets. The average of log total assets is 8.26, and the minimum and maximum values are 3.68 and 12.87 respectively, with a standard deviation of 1.86 . The mean leverage ratio for pharmaceutical companies is 1.94 percent; the minimum and maximum leverage values range from 0.00 to 104.60 , with a standard deviation of 9.36. The standard deviation is large which indicates that large variation in the financial leverage used by pharmaceutical companies; this illustrates that the majority of the pharmaceutical companies do not use debt for financing their business. This is understandable as all pharmaceutical companies in the sample are listed on BSE which allows firms to go for unlimited access to equity capital. Board directors' composition is used in this study for moderating the relationship between working capital liquidity ratios and firms' financial performance. Results in table (2) reveal that board directors in pharmaceutical companies consist of 0.53 percent independent directors as an average. The percentage of independent board directors in pharmaceutical companies' ranges between 0.00 and 0.88. 0 means that there is no independent board director on the board of the firm.

\subsection{Correlation}

Results in table (3) reveal that current ratio and quick ratio have a positive and significant relationship with return on assets, net operating margin and Tobin $Q$ at $1 \%$ level of significance. These results are in line with prior literature, e.g. (Bibi \& Amjad, 2017; Khidmat \& Rehman, 2014; Nassirzadeh \& Rostami, 2010; Priya \& Nimalathasan, 2013; Rehman et al., 2015).

Table 3: Correlations matrix

\begin{tabular}{|c|c|c|c|c|c|c|c|c|c|}
\hline & & ROA & NOM & TQ & CR & QR & LEVE & LOGTA & BDC \\
\hline ROA & Pearson Correlation & 1 & & & & & & & \\
\hline NOM & Pearson Correlation & $.582^{* *}$ & 1 & & & & & & \\
\hline $\mathrm{TQ}$ & Pearson Correlation & .395 & $.255^{\prime \prime}$ & 1 & & & & & \\
\hline $\mathrm{CR}$ & Pearson Correlation & $.289^{\prime \prime}$ & .120 & .148 & 1 & & & & \\
\hline QR & Pearson Correlation & $.264^{* *}$ & $.074^{*}$ & $.123^{\text {** }}$ & $.963^{\star *}$ & 1 & & & \\
\hline LEVE & Pearson Correlation & -.107 & -.099 & -.099 & -.014 & -.042 & 1 & & \\
\hline LOGTA & Pearson Correlation & .116 & .239 & $.297^{\prime \prime}$ & -.058 & $-.080^{\circ}$ & -.139 & 1 & \\
\hline BDC & Pearson Correlation & $-.078^{*}$ & .017 & $-.113^{* *}$ & $-.096^{* *}$ & $-.097^{*}$ & -.034 & $.137^{* 1 /}$ & 1 \\
\hline \multicolumn{5}{|c|}{ VIF } & 1.01 & - & 1.01 & 1.01 & 1.01 \\
\hline \multicolumn{5}{|c|}{ VIF } & & 1.01 & 1.01 & 1.01 & 1.01 \\
\hline \multicolumn{10}{|c|}{$\begin{array}{l}\text { (ROA) return on assets, (NOM) net operating margin, (TQ) Tobin Q, (LOGTA) Size of company (LEV) } \\
\text { Leverage of company, (CR) current ratio, (QR) quick ratio } \\
\text { **. Correlation is significant at the } 0.01 \text { level (2-tailed). } \\
\text { *. Correlation is significant at the } 0.05 \text { level ( } 2 \text {-tailed). }\end{array}$} \\
\hline
\end{tabular}

At the same time, some other studies contradict the result of this study, e.g. (Afrifa \& Padachi, 2016:Nassirzadeh \& Rostami, 2010). Findings in table (3) show that firms' size has a positive and significant association with the firms' financial performance measured by return on assets, net operating margin, and Tobin Q, these result are supported by some researchers e.g (Afrifa \& Padachi, 2016; Garcia-Teruel \& Martınez-Solano, 2007; Tahir \& Anuar, 2015; Tauringana \& Afrifa, 2013; Yazdanfar \& Öhman, 2014), while some other studies contradict with the results of this study e.g. (Pais \& Gama, 2015; Yunos et al., 2015). Leverage is one of the control variables used in this study, it was found that return on assets, net operating margin has a negative and significant correlation with leverage, this result is similar to the results found by (Tauringana \& Afrifa, 2013; 
Garcia-Teruel \& Martınez-Solano, 2007; Tahir \& Anuar, 2015; Yunos et al., 2015). On the other hand, some studies found a positive association between leverage and return on assets e.g. (Afrifa \& Padachi, 2016; Pais \& Gama, 2015). Finally, results in table (3) reveal that return on assets and Tobin $Q$ negatively and significantly associate with board composition at $5 \%$ of significant while net operating margin has a positive association with board directors' composition.

\subsection{GMM Estimation Analysis}

GMM estimator accounts for possible correlations between any of the independent variables (Athanasoglou, Brissimis \& Delis, 2008). Furthermore, Saona (2016) states that problems and issues related to individual heterogeneity are some justifications for using GMM. Both difference and system GMM estimators are suitable for situations with "small $\mathrm{T}$, large N" panels; independent variables that are not strictly exogenous; fixed individual effects; heteroscedasticity and autocorrelation (Roodman, 2006). The proposed models of the study are estimated by the generalized method of moments, and the results of the estimation are shown in Table 5 . To test the validity of instrument variables used in our GMM estimation, the three assumptions of GMM are met. Moreover, multicollinearity normality and linearity assumptions are checked, and they were met, Table 3 shows that the VIF values are less than two which mean there is no multicollinearity in the models. By visualizing histogram, we see that the residuals are normally distributed, P.P plot shows the linear relationship between the variables. To check the Heterogeneity, redundant fixed effects likelihood ratio was performed. Findings in table (4) show that all models have two-way variable intercept effect because cross-section fixed effect and period fixed effects for all models are significant $(p<0.05)$ except model $(1)$ which has only one way fixed effect intercept. Findings in the Table (5) show that in all models GMM lambda is significant, J-statistic is insignificant and AR (2) is insignificant. These indicate that GMM models are valid.

Table 4: Redundant fixed effects tests

\begin{tabular}{|l|l|c|c|l|c|c|}
\hline \multirow{2}{*}{ Model } & \multicolumn{3}{|c|}{ Test cross-section fixed effects } & \multicolumn{2}{c|}{ Test period fixed effects } \\
\cline { 2 - 7 } & Effects test & Statistic & Prob. & Effects test & Statistic & Prob. \\
\hline \multirow{2}{*}{ Model(1) ROA } & Cross-section F & 6.01 & 0 & Period F & 1.34 & 0.21 \\
\cline { 2 - 7 } & Cross-section Chi-square & 417.33 & 0 & Period Chi-square & 12.16 & 0.20 \\
\hline \multirow{2}{*}{ Model(2) ROA } & Cross-section F & 4.76 & 0 & Period F & 3.88 & 0.00 \\
\cline { 2 - 7 } & Cross-section Chi-square & 346.31 & 0 & Period Chi-square & 34.75 & 0.00 \\
\hline \multirow{2}{*}{ Model(3)NOM } & Cross-section F & 12.40 & 0 & Period F & 2.54 & 0.01 \\
\cline { 2 - 7 } & Cross-section Chi-square & 707.17 & 0 & Period Chi-square & 22.93 & 0.01 \\
\hline \multirow{2}{*}{ Model(5)TQ } & Cross-section F & 12.65 & 0 & Period F & 2.42 & 0.01 \\
\cline { 2 - 7 } & Cross-section Chi-square & 716.47 & 0 & Period Chi-square & 21.86 & 0.01 \\
\hline \multirow{2}{*}{ Model(6)TQ } & Cross-section F & 15.77 & 0 & Period F & 3.47 & 0.00 \\
\cline { 2 - 7 } & Cross-section Chi-square & 826.66 & 0 & Period Chi-square & 31.16 & 0.00 \\
\cline { 2 - 7 } & Cross-section F & 15.64 & 0 & Period F & 3.54 & 0.00 \\
\hline
\end{tabular}

Table 5: GMM estimates

\begin{tabular}{|c|c|c|c|c|c|c|c|c|c|}
\hline \multicolumn{10}{|c|}{ Regression models ROA is the dependent variable } \\
\hline \multicolumn{5}{|c|}{ Model (1) } & \multicolumn{5}{|c|}{ Model (2) } \\
\hline Variable & Coefficient & Std. Error & t-Statistic & Prob. & Variable & Coefficient & Std. Error & t-Statistic & Prob. \\
\hline $\mathrm{ROA}(-1)$ & 0.14 & 0.03 & 5.48 & 0 & $\mathrm{ROA}(-1)$ & 0.21 & 0.02 & 8.89 & 0 \\
\hline CR & 2.80 & 0.65 & 4.30 & 0 & QR & -23.38 & 8.68 & -2.69 & 0.0072 \\
\hline LEVE & 1.18 & 0.24 & 4.98 & 0 & LEVE & 0.40 & 0.15 & 2.67 & 0.0079 \\
\hline LOGTA & -4.83 & 0.70 & -6.92 & 0 & LOGTA & -7.50 & 1.61 & -4.66 & 0 \\
\hline $\mathrm{BDC}^{*} \mathrm{CR}$ & -15.63 & 2.95 & -5.30 & 0 & $\mathrm{BDC}^{*} \mathrm{QR}$ & -14.37 & 3.47 & -4.14 & 0 \\
\hline Prob(J-statistic) & \multicolumn{4}{|c|}{0.52} & Prob(J-statistic) & \multicolumn{4}{|c|}{0.32} \\
\hline $\mathrm{AR}(1)$ & \multirow{2}{*}{\multicolumn{4}{|c|}{0.02}} & $\mathrm{AR}(1)$ & \multicolumn{4}{|c|}{0.02} \\
\hline $\mathrm{AR}(2)$ & & & & & $A R(2)$ & \multicolumn{4}{|c|}{0.57} \\
\hline
\end{tabular}




\begin{tabular}{|c|c|c|c|c|c|c|c|c|c|}
\hline \multicolumn{10}{|c|}{ Regression models NOM is the dependent variable } \\
\hline \multicolumn{5}{|c|}{ Model (3) } & \multicolumn{5}{|c|}{ Model (4) } \\
\hline Variable & Coefficient & Std. Error & t-Statistic & Prob. & Variable & Coefficient & Std. Error & t-Statistic & Prob. \\
\hline $\mathrm{OM}(-1)$ & 0.78 & 0.07 & 11.17 & 0.00 & $\mathrm{OM}(-1)$ & 0.79 & 0.07 & 11.55 & 0.00 \\
\hline $\mathrm{CR}$ & -0.91 & 1.19 & -0.76 & 0.45 & QR & -0.11 & 1.35 & -0.08 & 0.94 \\
\hline LEVE & 0.49 & 0.22 & 2.20 & 0.03 & LEVE & 0.57 & 0.19 & 2.94 & 0.00 \\
\hline LOGTA & 8.80 & 3.32 & 2.65 & 0.01 & LOGTA & 8.70 & 3.21 & 2.71 & 0.01 \\
\hline $\mathrm{BDC}{ }^{*} \mathrm{CR}$ & 10.00 & 4.70 & 2.13 & 0.03 & $B D C^{*} Q R$ & 11.63 & 5.93 & 1.96 & 0.05 \\
\hline Prob(J-statistic) & \multicolumn{4}{|c|}{0.31} & Prob(J-statistic) & \multicolumn{4}{|c|}{0.28} \\
\hline $\mathrm{AR}(1)$ & \multicolumn{4}{|c|}{0.00} & $\mathrm{AR}(1)$ & \multicolumn{4}{|c|}{0.00} \\
\hline $\mathrm{AR}(2)$ & \multicolumn{4}{|c|}{0.68} & $\mathrm{AR}(2)$ & \multicolumn{4}{|c|}{0.80} \\
\hline
\end{tabular}

\begin{tabular}{|c|c|c|c|c|c|c|c|c|c|}
\hline \multicolumn{10}{|c|}{ Regression models TQ is the dependent variable } \\
\hline \multicolumn{5}{|c|}{ Model (5) } & \multicolumn{5}{|c|}{ Model (6) } \\
\hline Variable & Coefficient & Std. Error & t-Statistic & Prob. & Variable & Coefficient & Std. Error & t-Statistic & Prob. \\
\hline $\mathrm{TQ}(-1)$ & 0.21 & 0.03 & 7.05 & 0.00 & $\mathrm{TQ}(-1)$ & 0.20 & 0.03 & 7.17 & 0.00 \\
\hline CR & 0.69 & 0.10 & 7.17 & 0.00 & QR & 0.71 & 0.14 & 5.23 & 0.00 \\
\hline LEVE & -0.07 & 0.06 & -1.31 & 0.19 & LEVE & -0.12 & 0.07 & -1.66 & 0.10 \\
\hline LOGTA & 0.31 & 0.22 & 1.42 & 0.16 & LOGTA & 0.38 & 0.27 & 1.38 & 0.17 \\
\hline $\mathrm{BDC}^{*} \mathrm{CR}$ & 0.20 & 0.44 & 0.47 & 0.64 & $\mathrm{BDC}^{*} \mathrm{QR}$ & 2.94 & 0.75 & 3.92 & 0.00 \\
\hline Prob(J-statistic) & \multicolumn{4}{|c|}{0.05} & Prob(J-statistic) & \multicolumn{4}{|c|}{0.05} \\
\hline $\mathrm{AR}(1)$ & \multicolumn{4}{|c|}{0.00} & $\mathrm{AR}(1)$ & \multicolumn{4}{|c|}{0.00} \\
\hline$A R(2)$ & \multicolumn{4}{|c|}{0.32} & AR(2) & \multicolumn{4}{|c|}{0.25} \\
\hline
\end{tabular}

ROA) return on assets, (NOM) net operating margin, (TQ) Tobin Q, (, (SIZ) Size of company (LEV) Leverage of company, (CR) current ratio, (QR) quick ratio

\subsubsection{Direct effect}

The outcomes of models 1,3 and 5 in table (5) demonstrate the impact of current liquidity ratio on the financial performance of pharmaceutical companies listed on BSE. Results show that the coefficient of current ratio in model 1,2 , and are $2.80,-0.91$ and 0.69 respectively. The coefficient indicates that current ratio positively and significantly affects the financial performance of pharmaceutical companies measured by return on assets and Tobin $Q$. It means that when the current ratio increases by one percent return on assets and Tobin $Q$ will increase by 2.80 and 0.69 percent. The findings in models 1, 3, 5 show that leverage, firms' size, and age significantly affect return on assets and net operating margin. Furthermore, they insignificantly impact the financial performance of pharmaceutical companies measured by Tobin $Q$.

The results in model 2, 4 and 6 show the GMM estimates that examine the impact of quick ratio on the financial performance of pharmaceutical companies listed on BSE. -23.38 and 0.71 are the coefficient of the quick ratio in model 2, and 6 respectively, these coefficients mean that quick ratio has a positive impact on Tobin $Q$ and a negative impact on return on assets, these impacts are significant at 0.01 level of significance. This coefficient means when the quick ratio of pharmaceutical companies goes up by one percent, return on assets will decrease by one percent and when quick ratio increases by one percent Tobin $Q$ increases by 0.71 percent. Furthermore, results of model 4 show that quick ratio has an insignificant impact on firms' performance as measured by net operating margin.

\subsubsection{Indirect effect}

Results of model 1, 2, 3, 4, 5 and 6 in table (5) also show the moderation effect of board directors' composition on the relationship between, current ratio, quick ratio and the financial performance of pharmaceutical companies. Findings in model 3 and 4 reveal that board composition has indirect effect on net operating margin in other word, board directors' composition moderate the association between current ratio, quick ratio and firms' performance measured by net operating margin. Kim et al. (2001) argue that when the interaction term produces a significant coefficient, it means that there is a moderation effect. Results in model 5 show that board directors' composition does not moderate the association between current ratio and firms' performance measured by Tobin $Q$. without the interaction effect, current ratio has a significant and positive impact on Tobin $Q$ $(P . V<0.01)$ after introducing the interaction effect, the impact became insignificant $(P>0.05)$. 
Furthermore, findings of model 1, 2 and 6 show that there is an indirect effect, as the independent variables with and without the interaction term are significantly impacting the financial performance and also there is a change in the coefficient of the impact after introducing the interaction effect. This means that board directors' composition moderates the impact of current and quick ratio on the financial performance of pharmaceutical companies.

\section{Conclusion}

This study attempted to introduce the moderation effect into the existing literature. Kim et al. (2001) argue that when the interaction term produces a significant coefficient, it means that there is a moderation effect. The present study aimed to examine the impact of current ratio and liquidity ratio on the financial performance of Indian pharmaceutical companies. Furthermore, it attempted to find out if corporate governance moderates the relationship between liquidity ratios and firms' performance. The analysis of this paper is based on a panel data approach of 82 pharmaceutical companies, for the period from 2008 to 2017. GMM model is used for estimating the results. The study used two accounting based measures, return on assets and net operating profit, and one marketing based measure as proxies for firms' financial performance. Current ratio and quick ratio are the independent variables. Leverage, firms' size and age are used as control variables. Corporate governance measured by board directors' composition is used as a moderator variable. Normality, linearity, and multicollinearity assumptions are met in all regression models. Furthermore, the three assumptions of the GMM model were met too. The study found that current ratio and quick ratio significantly and positively impact pharmaceutical companies' financial performance measured by return on assets and Tobin Q. Moreover, it was found that corporate governance moderates the relationship between current ratio, quick ratio, and net operating margin. This paper clearly states that pharmaceutical companies are efficiently managing their liquidity, as they are highly liquid and their liquidity ratio has a positive association with the financial performance. This study is beneficial for financial managers, investors, suppliers and decision makers.

\section{References}

Abuzayed, B. (2012). Working capital management and firms ' performance in emerging markets: The case of Jordan. International Journal of Managerial Finance, 8(2), $155-179$. https://doi.org/10.1108/17439131211216620

Achchuthan, S., \& Kajananthan, R. (2013). Corporate governance practices and working capital management efficiency: special reference to listed manufacturing companies in Sri Lanka. Information and Knowledge Management, 3(2), 216-226. Retrieved from http://search.ebscohost.com/login.aspx?direct=true \&profile=ehost $\&$ scope $=$ site \&authtype $=$ crawler $\&$ jrnl=2224896X\&AN=89001541\&h=a0sz9CdC4XqZ9yIDpP B2Tx2g9MNLI3iGFr01w324fUSmUMTnsCUuQpadfpasd96phCUhlgFUz/K+lx+n5z64yw==\&crl=c

Afrifa, G. A. (2016). Net working capital, cash flow, and performance of UK SMEs. Review of Accounting and Finance, 15(1). https://doi.org/10.1108/RAF-02-2015-0031

Afrifa, G. A., \& Padachi, K. (2016). Working capital level influence on SME profitability. Journal of Small Business and Enterprise Development, 23(1), 44-63.

Agrawal, A., \& Knoeber, C. . (1996). Firm performance and mechanisms to control agency problems between managers and shareholders. J. Financ. Quant. Anal, (31), 377-397.

Ajao, O. S., \& Adebayo, A. S. (2010). The study of Wworking capital management as afinancial strategy ( A case study of Nestle Nigeria PLC ). Asian Journal of Business and Management Sciences, 2(4), 1-8.

Al-Homaidi, E. A., Tabash, M. I., Farhan, N. H., \& Almaqtari, F. A. (2019). The determinants of liquidity of Indian listed commercial banks: A panel data approach. Cogent Economics \& Finance, 7(1), 1616521

Almaqtari, F. A., Al-Homaidi, E. A., Tabash, M. I., \& Farhan, N. H. (2019). The determinants of profitability of Indian commercial banks: A panel data approach. International Journal of Finance \& Economics, 24(1), 168-185.

Anil. (2015). Impact of working capital management on profitability (A study of Indian manufacturing companies). Maharshi Dayanand University.

Athanasoglou, P. P., Brissimis, S. N., \& Delis, M. D. (2008). Bank-specific, industry-specific and macroeconomic determinants of bank profitability. Int. Fin. Markets, Inst. and Money, 18, 121-136. https://doi.org/10.1016/j.intfin.2006.07.001 
Bagchi, B., Chakrabarti, J., \& Roy, P. B. (2012). Influence of working capital management on profitability: A study on Indian FMCG companies. International Journal of Business and Management, 7(22), 1-10. https://doi.org/10.5539/ijbm.v7n22p1

Banos-Caballero, S., Garcı-Teruel, P. J., \& Martınez-Solano, P. (2012). How does working capital management affect the profitability of Spanish SMEs? Small Business Economics, 39(2), 517-529. https://doi.org/10.1007/s11187-011-9317-8

Bhagat, S., \& Bolton, B. (2008). Corporate governance and firm performance. J. Corp. Finance, (14), $257-273$.

Bhunia, A. (2013). Importance of Liquidity Management on Profitability. Journal of the Department of Commerce University of Kalyani, 4(975-746), 43-53.

Bhunia, A., Khan, I., \& MuKhuti, S. (2011). a Study of Managing Liquidity. Journal of Management Research, 3(2). https://doi.org/10.5296/jmr.v3i2.574

Bibi, N., \& Amjad, S. (2017). The relationship between liquidity and firms 'profitability : A case study of Karachi Stock Exchange. Asian Journal of Finance \& Accounting. https://doi.org/10.5296/ajfa.v9i1.10600

Chauhan, Y., Lakshmi, K. R., \& Dey, D. K. (2016). Corporate governance practices, self-dealings, and firm performance: Evidence from India. Journal of Contemporary Accounting \& Economics, 12(3), 274-289. https://doi.org/10.1016/j.jcae.2016.10.002

Deloof, M. (2003). Does working capital management affect profitability of Belgian firms ? Joimial of Business Fiiunife If.Aicmmting, 30(May).

Department of Pharmaceuticals. (2017). Annual Report 2016-17. Department of Pharmaceuticals. https://doi.org/10.1017/CBO9781107415324.004

Duffhues, P., \& Kabir, R. (2008). Is the pay-performance relationship always positive? Evidence from the Netherlands. J. Multinatl. Financ. Manage, (18), 45-60.

Duncan, N. M., Njeru, A., Member, F., \& Tirimba, O. I. (2015). Effect of cash management on financial performance of Deposit Taking SACCOs in Mount Kenya Region. International Journal of Scientific and Research Publications, 5(2), 1-7.

Egbide, B.-C., Uwuigbe, O., \& Uwalomwa, U. (2013). Liquidity management and profitability of manufacturing companies in Nigeria. Journal of Business and Management, 9(1), 13-21.

Elangkumaran, P., \& Karthika, T. (2013). An analysis of liquidity, profitability and risk: - A study of selected listed food, beverage and tobacco companies in Sri Lanka. 3rd International Conference, South Eastern University of Sri Lanka, (1), 1-7.

Eljelly, A. M. A. (2004). Liquidity - profitability tradeoff: An empirical investigation in an emerging market. International Journal of Commerce and Management, 14(2), 48-61.

Emery, G. W. (1984). Measuring short-term liquidity. Measuring Short-Term Liquidity, 4(4), $25-32$.

Farris, I. I., Theodore, M., \& Hutchison, P. D. (2002). Cash-to-cash: the new supply chain management metric. International Journal of Physical Distribution \& Logistics Management, 32(4), 288-298.tric. International Journal of Physical Distribution and Logistics Management, 32(4), 288-298.

Ganesan, V. (2007). An analysis of working capital management efficiency in telecommunication equipment industry. Rivier Academic Journal, 3(2), 1-10. Retrieved from http://www.rivier.edu/journal/ROAJ-Fall2007/J119-Ganesan.pdf

Garcia-Teruel, P. J., \& Martınez-Solano, P. (2007). Effects of working capital management on SME profitability. International Journal of Managerial Finance, 3(2), 164-177. https://doi.org/10.1108/17439130710738718

Geethalakshmi, A., \& Jothi, K. (2016). A Study on profitability position of Pharmaceutical Industry in India. International Journal of Advance Research in Computer Science and Management Studies, 4(4).

Hemalatha, P., \& Under. (2005). A study of the financial structure, liquidity and profitability of the silk weavers cooperative reader in commerce. Bharathidasan University.

Jackling, B., \& Johl, S. (2009). Board structure and firm performance: evidence from India's top companies. Corp. Gov.: An Int. Rev, (17), 492-509.

Johl, S. K., Kaur, S., \& Cooper, B. J. (2015). Board characteristics and firm performance: Evidence from Malaysian public listed firms. Journal of Economics, Business and Management, 3(2), $239-243$. https://doi.org/10.7763/JOEBM.2015.V3.187

Kamath, R. (1989). How useful are common liquidity measures? Journal of Cash Management, 9(1), 24-28.

Khidmat, W. Bin, \& Rehman, M. U. (2014). Impact of liquidity \& solvency on profitability chemical sector of Pakistan. Economics Management Innovation, 6(3), 3-13.

Kim, J.-S., Kaye, J., \& Wright, L. K. (2001). Moderating and mediating effects in causal models. Issues in Mental Health Nursing, 15(1), 59-66. https://doi.org/10.3109/01612849409074934

Mehta, M. S. P. (2017). Working capital management and firms ' profitability: Evidence from emerging Asian countries. South Asian Journal of Business Studies, 6(1 pp).

Morgheim, S. M. (2015). Assessing the relationship between financial slack and financial corporation performance. Northcentral University.

Muniandy, B., \& Hillier, J. (2015). Board independence, investment opportunity set and performance of South African firms. Pac.-Basin Finance J, 108-124. 
Mushtaq, H., Chishti, A. F., Kanwal, S., \& Saeed, S. (2015). Trade off between liquidity and profitability. International Journal of Scientific Research and Management, 3(5), 2823-2842. https://doi.org/2823-2842

Nassirzadeh, F., \& Rostami, A. (2010). Studying the relationship between liquidity indices ( traditional and modern ) and the profitability of Companies listed in Tehran Stock Exchange. Accounting and Auditing Review, (0098511), 1-17.

Nilsson, G. O. (2007). Corporate governance in Turkey. European Business Organization Law Review (EBOR), 8(02), 195. https://doi.org/10.1017/S1566752907001954

Niresh, J. A. (2012). Trade-off between liquidity \& profitability: A study of selected manufacturing firms in Sri lanka. Journal of Arts, Science \& Commerce, 3(4), 34-40.

Owolabi, S. A., Obiakor, R. T., \& Okwu, A. T. (2011). Investigating liquidity-profitability relationship in business organizations: A study of selected quoted Companies in Nigeria. British Journal of Economics, Finance and Management Sciences September 2011, Vol. $1 \quad$ (2), 1(2), $11-29$. https://doi.org/10.1017/CBO9781107415324.004

Owolabi, S. A., \& Obida, S. S. (2012). Liquidity management and corporate profitability: Case study of selected manufacturing companies listed on the Nigerian Stock Exchange. Business Management Dynamics, 2(2), 10-25. Retrieved from www.bmdynamics.com

Padiya, H. J. (2015). Working capital management of selected pharmaceutical units in Gujarat. Sardar Patel University.

Pais, M. A., \& Gama, P. M. (2015). Working capital management and SMEs profitability: Portuguese evidence. International Journal of Managerial Finance, 11(3), 341-358. https://doi.org/10.1108/IJMF-11-2014-0170

Pandey, N. S., Sugumari, G., \& Azhagaiah, R. (2016). The impact of working capital management on profitability of pharmaceutical industry in India. Pacific Business Review International, 9(6).

Priya, K., \& Nimalathasan, B. (2013). Liquidity management and profitability: A case study of listed manufacturing companies in Sri Lanka. Technological Exploration and Learning (IJTEL), 2(4), 161-165.

Raheman, A., Afza, T., Qayyum, A., \& Bodla, M. A. (2010). Working capital management and corporate performance of manufacturing sector in Pakistan. International Research Journal of Finance and Economics, 47(47).

Rehman, M. Z., Khan, M. N., \& Khokhar, I. (2015). Investigating liquidity-profitability relationship : Evidence from companies listed in Saudi stock exchange (Tadawul). Journal of Applied Finance \& Banking, 5(3), 159173.

Rhoades, D. L., Rechner, P. L., \& Sundaram, C. (2017). Board composition and financial performance: A Metaanalysis of the influence of outside directors. Journal of Managerial ISSUES, 12(1), 76-91.

Roodman, D. (2006). How to do xtabond2: An introduction to difference and system GMM in Stata. Center for Global Development Working Paper (103).

Saleem, Q., \& Rehman, R. U. (2011). Impacts of liquidity ratios on profitability (Case of oil and gas companies of Pakistan). Interdisciplinary Journal of Research in Business, 1(July), 95-98.

Saona, P. (2016). Intra- and extra-bank determinants of Latin American Banks 'pro fi tability. International Review of Economics and Finance, 45, 197-214. https://doi.org/10.1016/j.iref.2016.06.004

Shah, A. B. (2000). Problems of working capital management of selected pharmaceutical companies of Maharashtra State. University Of Baroda.

Tabash, M. I., Yahya, A. T., \& Akhtar, A. (2017, November). Financial Performance Comparison of Islamic and conventional banks in the United Arab Emirates (UAE). In International Conference on Advances in Business, Management and Law (ICABML) 2017 (Vol. 1).

Tahir, M., \& Anuar, M. B. A. (2015). The determinants of working capital management and firms performance of textile sector in pakistan. Quality \& Quantity, 50(2), 605-618. https://doi.org/10.1007/s11135-015-0166-4

Tauringana, V., \& Afrifa, G. A. (2013). The relative importance of working capital management and its components to SMEs ' profitability. Journal of Small Business and Enterprise Developmen, 20(3), 453469. https://doi.org/10.1108/JSBED-12-2011-0029

Tran, H., Abbott, M., \& Yap, C. J. (2017). How does working capital management affect the profitability of Vietnamese small and medium sized enterprises? Journal of Small Business and Enterprise Development, 24(1).

Ukaegbu, B. (2014). The significance of working capital management in determining firm profitability: Evidence from developing economies in Africa. Research in International Business and Finance, 31, 1-16. https://doi.org/10.1016/j.ribaf.2013.11.005

Vahid, T. K., Elham, G., Mohsen, A. khosroshahi, \& Mohammadreza, E. (2012). Working capital management and corporate performance: Evidence from Iranian companies. Procedia - Social and Behavioral Sciences, 62, 1313-1318. https://doi.org/10.1016/j.sbspro.2012.09.225

Vijayalakshmi, V., \& Srividya, M. (2015). A study on working capital management of pharmaceutical industry in India. Journal of Management and Science, 5(3), 59-80.

Wang, Y.-J. (2002). Liquidity management, operating performance, and corporate value: evidence from Japan and Taiwan. Journal of Multinational Financial Management 12, 12, 159-169. 
Yahya, A. T., Akhtar, A., \& Tabash, M. I. (2017). The impact of political instability, macroeconomic and bankspecific factors on the profitability of Islamic banks : an empirical evidence. Investment Management and Financial Innovations, 14(4), 30-39. https://doi.org/10.21511/imfi.14(4).2017.04

Yameen, M., Farhan, N. H., Tabash, M. I. (2019). The impact of corporate governance practices on firm's performance: An empirical evidence from Indian tourism sector. Journal of International Studies, 12(1), 208-228. doi:10.14254/2071-8330.2019/12-1/14

Ware, E. O. (2015). Liquidity management and its effect on profitability in a tough economy: ( A case of companies listed on the Ghana Stock Exchange ). International Journal of Research in Business Studies and Management, 2(11), 34-66.

Yang, T., \& Zhao, S. (2014). CEO duality and firm performance: evidence from an exogenous shock to the competitive environment. J. Bank. Finance, (4), 534-552.

Yazdanfar, D., \& Öhman, P. (2014). The impact of cash conversion cycle on firm profitability An empirical study based on Swedish data. International Journal of Managerial Finance, 10(4), 442-452. https://doi.org/10.1108/IJMF-12-2013-0137

Yunos, R. M., Nazaruddin, N., Ghapar, F. A., Ahmad, S. A., \& Zakaria, N. B. (2015). Working capital management in Malaysian government-linked companies. Procedia Economics and Finance, 31(15), 573-580. https://doi.org/10.1016/S2212-5671(15)01203-4

Zabri, S. M., Ahmad, K., \& Wah, K. K. (2016). Corporate governance practices and firm performance : Evidence from top 100 public listed companies in Malaysia. Procedia Economics and Finance, 35(October 2015), 287-296. https://doi.org/10.1016/S2212-5671(16)00036-8

Zygmunt, J. (2013). Does liquidity impact on profitability? A case of polish listed IT companies. Conference of Informatics and Management Sciences, 247-251.

\section{Appendices}

Appendix (A): Normality
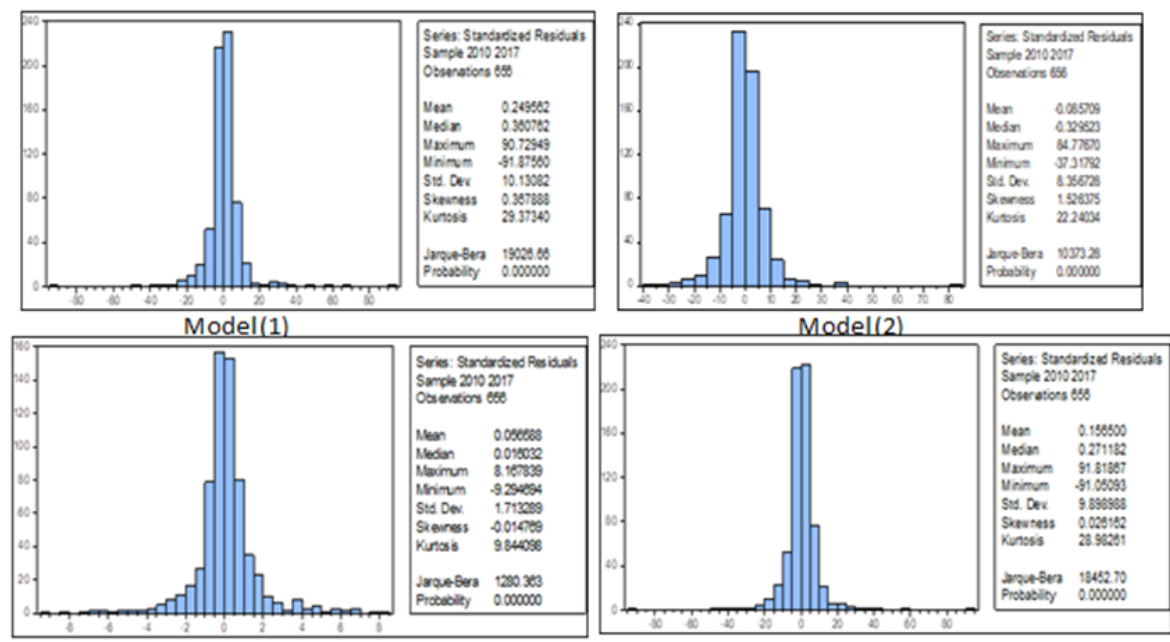

Model(3)
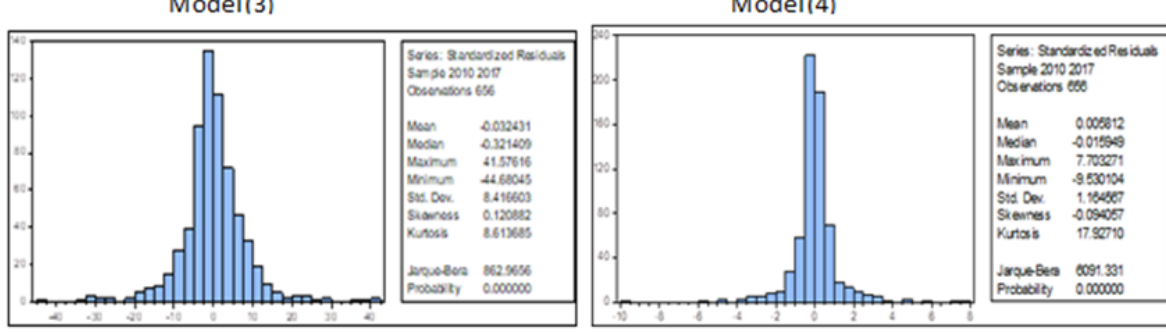

Model(5)

Model(6) 
Appendix (B): Linearity

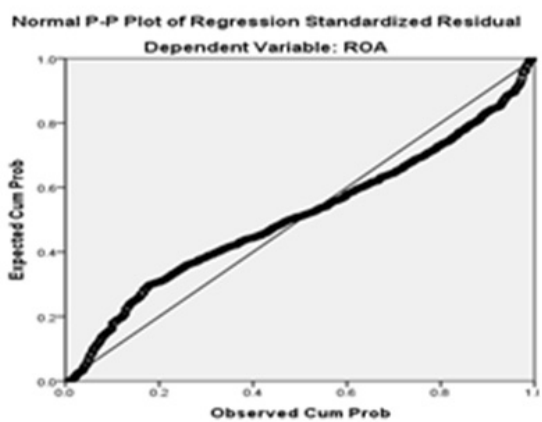

Model(1)

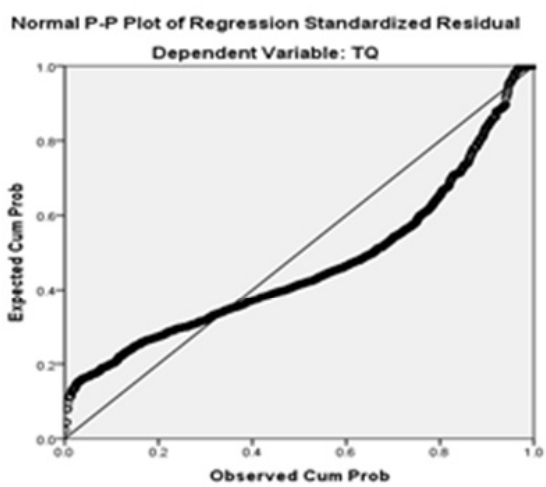

Model (3)

Normal P.P Plot of Regression Standardized Residual

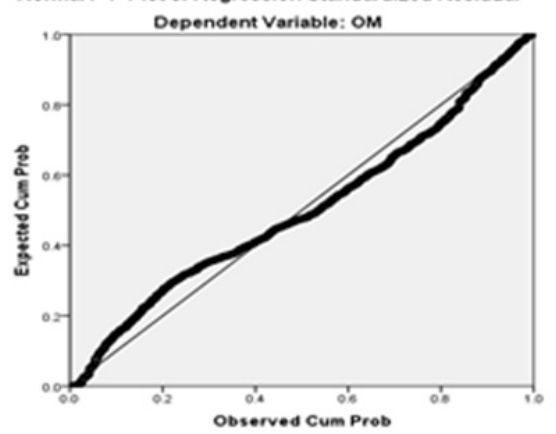

Model (5)

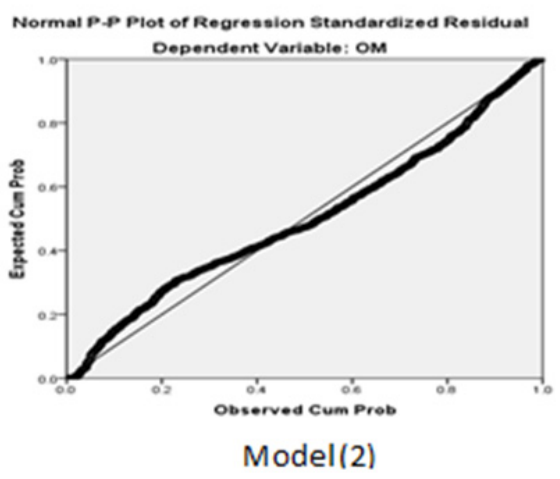

Normal P.P Plot of Regression Standardized Residual

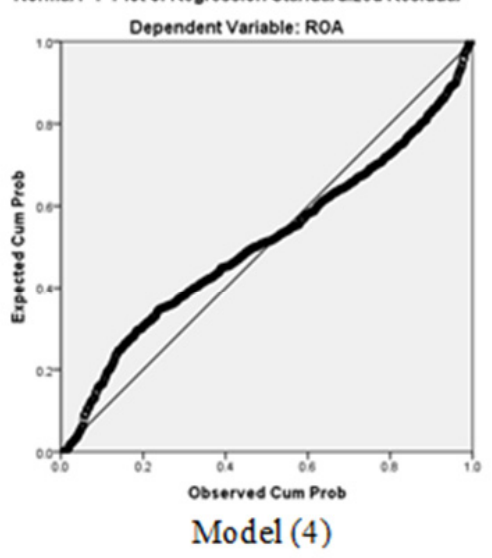

Normal P.P Plot of Regression Standardized Residual

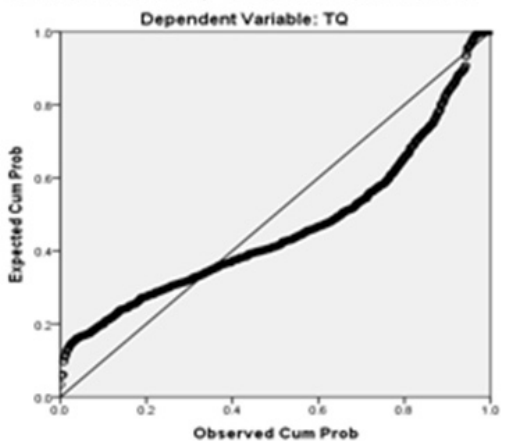

Model (6) 